ROCZNIK ADMINISTRACJI PUBLICZNEJ 2019 (5)

ARTYKUŁY Prawo i administracja Unii Europejskiej / Law and Administration

of the European Union

DOI 10.4467/24497800RAP.19.007.11470

http://www.ejournals.eu/RAP/

ISSN 2449-7800 (online), ISSN 2449-7797 (print), p. 115-124

YarosLav Hapanovych ${ }^{1}$

\title{
Prospects for the Implementation of the European Experience of E-Democracy and E-Government in Ukraine
}

\section{General problem statement}

As regards European integration, Ukrainian public authorities and citizens face the task of ensuring transparency and accountability of the government, involving citizens in decision-making and rallying communities around democratic values based on the European experience of e-governance and e-democracy. The Digital Agenda for Europe ${ }^{2}$ is one of the seven flagship initiatives of the Europe 2020 strategy. The Digital Agenda proposes measures to be taken immediately to move to smart, sustainable and inclusive growth in Europe. These measures include the creation of conditions for long-term changes that will be caused by the development of the digital economy and society.

Development in e-governance and e-democracy in Ukraine is evolutionarily related to the study of good practices in the European Union as regards the creation and use of public administration with ICT technologies as well as the need for their implementation and application in public life and economy (e-government and e-democracy, e-identification of persons, e-voting and electronic addresses, Blockchain, electronic banking, cyber security, etc.) taking into consideration national peculiarities. Electronic services and tools to access information, involving citizens in decision-making and improving their digital skills and competencies fill modern social life with a new meaning, the basis of which is European knowledge, regulations, electronic technology and trained professionals in the field.

In today's reality, the European Union seeks to ensure a wider and more efficient use of digital technology that gives Europe an opportunity to solve its major problems that will improve the quality of life of Europeans, in

1 Yaroslav Hapanovych, Ph.D., O.S. Popov Odessa National Academy of Telecommunications.

2 Digital agenda for Europe, European Commission, Brussels 2010, Retrieved from https://ec.europa.eu/digital-single-market/en/digital-agenda-europe-key-publications (accessed 7.7.2019). 
particular, provide better health care, safer and efficient transport, a cleaner environment, new opportunities in media and easier access to public services and cultural development ${ }^{3}$. This is vital, in particular, for the development of democratic processes, public administration and fighting corruption.

\section{Analysis of recent research and problem definition}

Problems of governance, including e-democracy and e-government, have been investigated by Averyanov IN., Atamanchuk G., Balabayeva C.K. Belyakov, Hrytsiak N.V. Dreshpak, Zhyliaiev I. Food M., Kandzyuba I. Klimushyn P., Lozhkovskyy A. Mamatova T. Misnykov Yu Polumiyenko S. Yu Pigarev, Semenchenko A. Serenok A., J. Tomkova, Hoshaba A., and S. Chukut.

The article offers an analysis of the state of the implementation of e-government and e-democracy tools using the example of the city of Odessa in Ukraine and outlines prospects of future development.

\section{Main material research}

Like every European country, Ukraine has its own way of e-governance and e-democracy, which depends on a number of influential factors. These factors, firstly, should include the form of government and political regime. In a country with no or little democracy, a totalitarian form of governance, there usually exist many difficulties in terms of the application of e-democracy tools. Therefore, while reformatting power in a country it is important to continue to maintain a democratic government, including the strengthening of the parliamentary component and a balance of powers. Secondly, there is corruption. In a corrupt country, it is much more difficult to implement and develop mechanisms for e-government and e-democracy because it is not profitable to the corrupt elites and individual corrupt persons of authority. Thirdly, ${ }^{4}$ another influential factor is the presence of informative websites of public authorities, sufficient telecommunications networks and quality electronic services in administrative units (village, district, city, region, state). Fourth, a significant impact on the development of e-governance and e-democracy is exerted by the level of digital literacy. No matter how rapidly technology develops, the use of available electronic services depends on public awareness, the ability to use the cyber environ-

3 Yevropeys'kyy dosvid normatyvno-proektnoho zabezpechennya rozvytku informatsiynoho suspil'stva: vysnovky dlya Ukrayiny [Analitychnyy zvit], National Institute for Strategic Studies, 2014, p. 8, Kyiv, retrieved from http://old2.niss.gov.ua/content/articles/files/Gnatyuk-59546.pdf (accessed 7.7.2019).

4 J. Pigharjev, A. Lozhkovsjkyj, Y. Hapanovych, IT-arkhitektura systemy elektronnogho urjaduvannja, in: Elektronne uryaduvannya ta elektronna demokratiya: Navch. 15 posib.: u ch., A.I. Semenchenka, V.M. Dreshpaka eds., Kyiv 2017, p. 64. 
ment and corresponding terminals (of telecommunication equipment) and software as well as the availability of consumer access to these services.

In Ukraine, the legal process for e-government and e-democracy is based on the Ukrainian Constitution and the legislation governing the development of public administration with the use of ICT technologies. It started with the adoption of such regulations as the act on the National Informatisation Programme, ${ }^{5}$ the act on the electronic document ${ }^{6}$ and was further developed by the act on electronic trust services ${ }^{7}$. However, the acts regulating the development of technical and technological architecture and infrastructure require further creation and development. Analysis of the information content of official sites of local state administrations in the Odessa region indicates the absence of specific and statistical information as well as the characteristics foreseen in the publication of the Cabinet of Ministers of Ukraine of 4 January 2002 No. 3 on the procedure governing the publication on the Internet of information on the activities of the executive power ${ }^{8}$. It concerns individual sites of district administrations, where not specified so necessary for public information purposes such as utilities, law enforcement agencies and schools; information about the payment of local taxes and fees; indicators of wages and other social benefits and energy performance calculations. The information to be published on the official website of each executive agency in the Odessa region is listed in Table 1. The fact that there is no such information on the website means that the instruments for storage and publishing of electronic data for improvement and implementation of activities of public authorities. Moreover, the completeness of the information published on the website is part of the transparency of public authorities and promotes the development of e-democracy in the country.

The basic principles, terminology and e-democracy tools defining the notion of e-democracy in Ukraine ${ }^{9}$ were approved by the Cabinet of Ministers of Ukraine in the 2018 Action Plan for its implementation

5 Act (1998) No. 74/98-BP of 4 February 1998. National Informatisation Programme, Verkhovna Rada of Ukraine, Kyiv, retrieved from http://zakon.rada.gov.ua/ laws/show/74/98-\%D0\%B2\%D1\%80 (accessed 7.7.2019).

6 Act (2003) No. 851-IV of 22 May 2003, Pro elektronni dokumenty ta elektronnyj dokumentoobigh, Verkhovna Rada of Ukraine, Kyiv, retrieved from http://zakon.rada. gov.ua/laws/show/851-15 (accessed 7.7.2019).

7 The Act (2017) No. 2155-VIII of 5 October 2017, Pro elektronni dovirchi poslughy, Verkhovna Rada of Ukraine, Kyiv, retrieved from http://zakon2.rada.gov.ua/laws/ show/2155-19 (accessed 7.7.2019).

8 Resolution of the Cabinet of Ministers of Ukraine (2002) No. 3 of 4 January 2002, Kyiv. Pro porjadok opryljudnennja u merezhi Internet informaciji pro dijaljnistj orghaniv vykonavchoji vlady, retrieved from https://zakon.rada.gov.ua/laws/show/32002-\%D0\%BF (accessed 7.7.2019).

9 Resolution of the Cabinet of Ministers of Ukraine (2017) No. 797-r of 8 November 2017. Kyiv. Pro skhvalennja Koncepciji rozvytku elektronnoji demokratiji v Ukrajini 
and involve: ensuring the application of a uniform policy in the field of e-democracy, promoting citizen accountability of government agencies, improving the mechanism for coverage of the activities of the state and improving e-democracy tools atnational and local levels.

Table 1. Information to be published on the official site of the executive authority (local administrations) for the period 2015-2018

\begin{tabular}{|c|c|c|c|c|c|}
\hline $\begin{array}{c}\text { Name } \\
\text { of the authority } \\
\text { (district } \\
\text { administration) } \\
\text { analysed }\end{array}$ & $\begin{array}{c}\text { Availability } \\
\text { of a secure } \\
\text { official } \\
\text { website }\end{array}$ & $\begin{array}{c}\text { List } \\
\text { of utilities, } \\
\text { law } \\
\text { enforcement } \\
\text { agencies } \\
\text { and schools } \\
\end{array}$ & $\begin{array}{l}\text { Information } \\
\text { on the } \\
\text { payment } \\
\text { of local taxes } \\
\text { and fees }\end{array}$ & $\begin{array}{l}\text { Indicators } \\
\text { of wages } \\
\text { and other } \\
\text { social } \\
\text { benefits }\end{array}$ & $\begin{array}{l}\text { Energy } \\
\text { performance } \\
\text { calculations }\end{array}$ \\
\hline \multicolumn{6}{|c|}{ Odessa region } \\
\hline $\begin{array}{c}\text { Odesa } \\
\text { Regional State } \\
\text { Administration }\end{array}$ & $\begin{array}{c}\text { is a secure } \\
\text { site }\end{array}$ & $\begin{array}{c}\text { Not } \\
\text { available }\end{array}$ & specified & $\begin{array}{c}\text { Not } \\
\text { available }\end{array}$ & $\begin{array}{c}\text { Not } \\
\text { available }\end{array}$ \\
\hline Anan'evska & not protected & missing & specified & missing & missing \\
\hline Artsyzka & not protected & missing & specified & missing & missing \\
\hline Baltska & not protected & missing & specified & missing & missing \\
\hline Belgorod-Dniester & not protected & missing & & & \\
\hline Berezevska & not protected & missing & missing & missing & missing \\
\hline Bilyayivska & not protected & missing & missing & missing & missing \\
\hline $\begin{array}{c}\text { Belgorod- } \\
\text {-Dnestrovska }\end{array}$ & not protected & missing & missing & for 2015 & for 2015 \\
\hline Velykomykhailevska & not protected & missing & missing & missing & missing \\
\hline Zaharevska & not protected & missing & missing & missing & missing \\
\hline Ivanevska & not protected & missing & missing & missing & missing \\
\hline Izmaelska & not protected & missing & missing & missing & missing \\
\hline Kilievska & not protected & missing & specified & missing & specified \\
\hline Kodymska & not protected & missing & specified & missing & missing \\
\hline Limanska & not protected & missing & missing & missing & missing \\
\hline Lyubashevska & not protected & missing & specified & missing & missing \\
\hline Nicholaevska & not protected & missing & missing & missing & missing \\
\hline Ovidiopol's'ka & not protected & missing & after 2018 & missing & missing \\
\hline Oknyanska & not protected & specified & missing & missing & missing \\
\hline Podelska & not protected & missing & after 2018 & missing & missing \\
\hline Reniiska & not protected & missing & missing & missing & missing \\
\hline Razdel'nyanska & not protected & missing & missing & missing & missing \\
\hline Savranska & not protected & missing & missing & missing & missing \\
\hline Saratska & not protected & missing & specified & missing & missing \\
\hline Tarutynska & not protected & specified & specified & specified & missing \\
\hline Tatarbunarska & not protected & missing & missing & missing & missing \\
\hline Shyryayivska & not protected & missing & missing & missing & missing \\
\hline
\end{tabular}

Note: The table shows the data from the author's own research.

ta planu zakhodiv shhodo jiji realizaciji. Retrieved from http://zakon2.rada.gov.ua/laws/ show/797-2017-\%D1\%80. 
Also envisaged are: providing electronic identification of individuals and organisations in public information and telecommunication systems, improving the quality of statistical and analytical information in the field of e-democracy, spreading the practice of using the tools of electronic voting and open use of public funds to ensure the development of open data, promoting electronic democracy by developing skills of using tools based on the availability of information for persons with disabilities, particularly with sensory impairments (including hearing and sight), and ensuring research and development of the electronic imaging of the state of democracy in Ukraine.

When analysing the willingness of society to perform such tasks, it should be noted that the existing legal framework on e-democracy, information and development of information society is already outdated and in need of improvement. Thus, the public really needs communication with experts to overcome the digital divide and master new technologies. Therefore, the policy of implementation of e-democracy and e-governance should be addressed to be resolved at the top as well as at the bottom.

Analysing the regulatory framework, one can conclude that the act on the National Informatisation Programme states that informatisation is a set of interrelated organisational, legal, political, socio-economic, scientifictechnical and manufacturing processes aimed at creating conditions to meet the information needs of citizens and society through the creation, development and use of information systems, networks, and resources in information technologies based on the use of modern computer and communication equipment ${ }^{10}$. It is clear that the issue of comprehensive support processes of e-governance and e-democracy require both citizens and the state. However, neither a national nor regional programme of information contains the necessary critical areas related to e-democracy and e-governance. Considering the issue on the example of the regional programme of information in the Odessa Region for 2018-2020 called the Electronic Odessa Region"11, it should be noted that this program does not include specific measures of e-democracy and e-governance, nor does it determine the strategy of solving the problems of information needs and information support in socio-economic, environmental, scientific, technical, defense, national-cultural and other activities in different areas of regional importance as provided for in Article 2 of the Act on the National Informatisation Programme. The first programme of information should focus by definition on not just the computerisation of public authorities

10 Act (1998) No. 74/98-VR of 4 February 1998, Pro nacionaljnu proghramu informatyzaciji, Verkhovna Rada of Ukraine,Kyiv, retrieved from http://zakon.rada.gov.ua/ laws/show/74/98-\%D0\%B2\%D1\%80 (accessed 7.7.2019).

11 Decision of the Odessa regional council of 14 March 2018 No. 658-VII. Odesa, Pro zatverdzhennja reghionaljnoji proghramy informatyzaciji Odesjkoji oblasti na 20182020 roky «Elektronna Odeshhyna»: retrieved from https://iac.odessa.gov.ua/wp-content/uploads/2018/09/programma-2018-658-VII.pdf (accessed 7.7.2019). 
in the region, as we see it, but also the development of all components of public life in the region using ICT, and above all - information technology communities and citizens, the development of the real economy, science, education, medicine, etc., as required by the Act. What is especially needed today is the improvement of digital skills of citizens, people who work in the public service and business (digital education of the public). It is possible to ensure results within the region on the material basis of higher technical education.

Secondly, this programme does not include specific measures: educational components of e-government and e-democracy on training people who work in the public sector and citizens; development of the digital economy; building a unified protected regional information and communication infrastructure. Along with this programme, it is necessary to highlight sectors providing e-democracy and e-governance in the region, such as: IT system architecture of e-government and e-democracy in towns and in the region as a whole; e-governance and e-democracy resources (human, material and non-material, etc.); e-democracy tools (e-petitions, e-partnership, e-voting, e-consultations, e-addresses, e-campaigning, e-counting and e-survey); net open data; ensuring cyber security, use of a comprehensive information security system of verified compliance for society, communities and businesses (protection of information and personal data rights, networks, electronic media, etc.); electronic interaction between public authorities, citizens and businesses using the relevant electronic systems; e-services organisations, higher education institutions and business; application of Electronic City and Electronic Region; activity of economic entities, institutions of higher education; electronic documents and e-records management; development of the digital economy of cities and the region as a whole; identification, and authentication of people in cyberspace (a basic description of the established standards, criteria and process indicator guarantee); the sector of state supervision (control). Public administration cannot be effected without one of the main management-control (supervision) functions. The process of information should be subject to state and public control (public examination) in individual state-level measures.

Thirdly, the programme lacks defined principles of financing based on the public-private partnership and is not incorporated by attracting existing business resources in the Odessa Region (information systems, telecommunication networks, communication channels and copyright software operators).

Moreover, the programme does not provide information service on Odessa public participation, relevant organisations, institutions of higher education (especially specialised ones) in the project selection programme. This does not correspond with the basic principles of the development of democracy in the region, which leads to confusion and public concern. 
Today, this pattern of inconsistencies is typical of many regions of Ukraine. Therefore, in our opinion, it is important for the country to study and implement best practices in e-government and e-democracy applied in European societies.

\section{Conclusions}

Thus, to solve these issues it is necessary to unite communities, combining the efforts of the state, civil society, business and citizens at local, regional and national levels.

First, it is necessary to establish regional community representatives as well as government, academic, business, local and regional working groups in order to develop mechanisms for the practical implementation of e-democracy and e-governance tools as well as their monitoring. Secondly, we should engage the public, business, educational and research institutions in decision-making on important issues (legal, technical, social, etc.) and identify the relevant resources. In this context, information programmes should attract specialised higher education institutions and researchers. Thirdly, the experience of developed countries indicates the need of developing standards and introducing civil services and local government officials (post certification of the positions). It is necessary to develop standards of compliance for experts in the fields of informatisation, e-government and e-democracy (by category). Finally, it is important to implement certification and passportisation of people who do office jobs in all spheres and sectors of Ukraine in accordance with the recommendations of the European Union and the international community, which also helps fight corruption. In this regard, the normalisation process is seen as promising additional training in compliance with the approved standards of the office posts at least once every five years. Additionally, the following measures are an important part of organisation and maintenance of public control and public examination of regional information programmes of the public authorities on the evaluation of their compliance with the standards. The available theory and practice of public administration measures of state supervision (control) as one of the key management functions in the areas of e-government and information are not registered and functionally not assigned to any central body of the executive power. It is therefore necessary to determine the body of state supervision (control) on e-governance and define its functions and powers as well as to control procedures with public participation.

An important question is bridging the digital divide and organising public training on the use of electronic document management systems, with including the creation of clean open data (big data) of the main areas of public life in the region - as a tool to attract investment to the region. The technology of e-governance and e-democracy should be accessible to 
people and improve their lives. To this end, specialised higher education institutions can attract students and faculty resources to teach citizens how to use electronic devices and applications.

To facilitate people's lives, the development of mechanisms for electronic services business enterprises is promising, namely: an online mutual reconciliation mechanism for utilities (gas, light, heat, water); e-counselling (rights, work, education, health, sport, travel, etc.); electronic resources to assist citizens and businesses; implementation of the Electronic School (Class E).

Thus, the need to implement the above objectives requires an advanced state of society and the implementation of an administrative and legal environment and IT technologies capable of providing a digital leap in Ukraine.

For the effective implementation of all regulatory mechanisms on e-governance and e-democracy, the key element is the development and implementation of policies of eco-strategy of good governance based on eco-awareness, eco-mechanisms, natural resources, accountability of public authorities and flexible regulation, implementation of interaction between civil society and the maximisation of their involvement in decision-making, ensuring public control and the elimination of social problems ${ }^{12}$.

The components that provide a digital leap from the European experience will be: the high level of active participation of citizens in decision-making, support for business, the government and the international community, the introduction of modern electronic systems such as Trembita for the protection of Ukraine; the introduction of guaranteed identification (authentication) and citizen protection in the cyberspace and the country's active cooperation with its European partners.

\section{Bibliography}

Pigharjev J., Lozhkovsjkyj A., Hapanovych Y., IT-arkhitektura systemy elektronnogho urjaduvannja, in: Elektronne uryaduvannya ta elektronna demokratiya: Navch. 15 posib.: u ch., A.I. Semenchenka, V.M. Dreshpaka (eds.), Kyiv 2017.

Hapanovych Y., Mekhanizmy derzhavnoji reghuljatornoji polityky u sferi zv'jazku ta informatyzaciji: shljakhy udoskonalennja, Odessa 2014.

National Institute for Strategic Studies, Yevropeys'kyy dosvid normatyvno-proektnoho zabezpechennya rozvytku informatsiynoho suspil'stva: vysnovky dlya Ukrayiny (Analitychnyy zvit), p. 8, Kyiv 2014, http://old2.niss.gov.ua/content/articles/files/Gnatyuk-59546.pdf (accessed 7.7.2019).

12 Y. Hapanovych, Mekhanizmy derzhavnoji reghuljatornoji polityky u sferi zv'jazku ta informatyzaciji: shljakhy udoskonalennja, Odessa 2014, p. 84-88. 
Digital agenda for Europe, European Commission, Brussels 2010, retrieved from https://ec.europa.eu/digital-single-market/en/digital-agenda-europe-key-publications (accessed 7.7.2019).

Act (1998) No. 74/98-BP of 4 February 1998, National Informatisation Programme, Verkhovna Rada of Ukraine, Kyiv, retrieved from http://zakon.rada.gov.ua/ laws/show/74/98-\%D0\%B2\%D1\%80 (accessed 7.7.2019).

Act (1998) No. 74/98-VR of 4 February 1998, Pro nacionaljnu proghramu informatyzaciji, Verkhovna Rada of Ukraine, Kyiv, retrieved from http://zakon.rada. gov.ua/laws/show/74/98-\%D0\%B2\%D1\%80 (accessed 7.7.2019).

Act (2003) No. 851-IV of 22 May 2003, Pro elektronni dokumenty ta elektronnyj dokumentoobigh, Verkhovna Rada of Ukraine, Kyiv, retrieved from http://zakon. rada.gov.ua/laws/show/851-15 (accessed 7.7.2019).

Act (2017) No. 2155-VIII of 5 October 2017, Pro elektronni dovirchi poslughy, Verkhovna Rada of Ukraine, Kyiv, retrieved from http://zakon2.rada.gov.ua/laws/ show/2155-19 (accessed 7.7.2019).

Resolution of the Cabinet of Ministers of Ukraine (2002) No. 3 of 4 January 2002, Kyiv, Pro porjadok opryljudnennja u merezhi Internet informaciji pro dijaljnistj orghani vvykonavchoji vlady, retrieved from https://zakon.rada.gov.ua/laws/ show/3-2002-\%D0\%BF (accessed 7.7.2019).

Resolution of the Cabinet of Ministers of Ukraine (2017) No. 797-r of 8 November 2017, Kyiv, Pro skhvalennja Koncepciji rozvytku elektronnoji demokratiji v Ukrajini ta planu zakhodiv shhodo jiji realizacji, retrieved from http://zakon2.rada. gov.ua/laws/show/797-2017-\%D1\%80 (accessed 7.7.2019).

Decision of the Odessa Regional Council of 14 March 2018 No. 658-VII, Odessa, Pro zatverdzhennja reghionaljnoji proghramy informatyzaciji Odesjkoji oblastina 2018-2020 roky «Elektronna Odeshhyna», retrieved from https:/iac.odessa. gov.ua/wp-content/uploads/2018/09/programma-2018-658-VII.pdf (accessed 7.7.2019).

Abstract

The article aims to highlight the perspectives of e-democracy and e-governance tools at national and regional levels as well as proposals for the use of ICT to improve public access to information, the quality of public administration and territorial cohesion of communities.

Keywords: e-democracy, accountability, participation, rallying communities, tools of e-governance and e-democracy, information and communication technologies, access to information

\section{Perspektywy wdrożenia na Ukrainie europejskich doświadczeń w zakresie demokracji elektronicznej i e-administracji}

Streszczenie

Celem niniejszego artykułu jest zaprezentowanie narzędzi demokracji elektronicznej oraz e-administracji na szczeblu krajowym i regionalnym oraz przedstawienie propozycji wykorzystania teleinformatyki na rzecz zwiększenia publicznej dostępności 
informacji, podniesienia jakości administracji publicznej oraz spójności terytorialnej różnych społeczności.

Słowa kluczowe: demokracja elektroniczna, rozliczalność, uczestnictwo, wspólnoty jednoczące, narzędzia e-administracji i e-demokracji, technologie teleinformatyczne, dostęp do informacji 